\title{
Studi Komparasi Tingkat Konsumsi Masyarakat Melalui E-Commerce Sebelum dan Sesudah Masa Pandemi Covid-19
}

\author{
Christa Ananda Fema ${ }^{1}$, Nandita Rakhmad ${ }^{1}$, Putri Yasmin E Eberthon Bonda ${ }^{1}$, Diki Ramli \\ 1, Agus Maulana ${ }^{1, \star}$ \\ ${ }^{1}$ Fakultas Ekonomi dan Bisnis; Universitas Pembangunan Nasional Veteran Jakarta; JI. RS. \\ Fatmawati, Pondok Labu, Jakarta Selatan, DKI Jakarta; Telp. (021) 765 6971; e-mail: \\ christaanandaa@gmail.com, nanditaraa@gmail.com, putriyasmineeberthonbonda@gmail.com, \\ dikiramli030102@gmail.com, agus.maulana@upnvj.ac.id \\ * Korespondensi: e-mail: agus.maulana@upnvi.ac.id
}

Submitted: 07/01/2022; Revised: 15/01/2022; Accepted: 26/01/2022; Published: 31/01/2022

\begin{abstract}
The Covid-19 pandemic has had a significant impact on the Indonesian economy, especially ecommerce. The use of e-commerce has increased, causing public consumption to also increase compared to before the pandemic. This study aims to determine the level of public consumption through e-commerce before and after the Covid-19 pandemic. The object of this research is UPN Veteran Jakarta students and several people who use e-commerce. This type of research is quantitative research with instruments in the form of online questionnaires, as well as descriptive quantitative data analysis techniques. The results show that the level of public consumption through e-commerce has increased after the Covid-19 pandemic. People believe in the system, they also claim that the costs incurred through e-commerce are relatively cheap compared to shopping in person.
\end{abstract}

Keywords: Consumption; Covid-19; E-commerce; Online Shopping; Online Questionnaires

\begin{abstract}
Abstrak
Pandemi Covid-19 telah memberikan dampak yang signifikan terhadap bidang perekonomian Indonesia khususnya e-commerce. Penggunaan e-commerce yang meningkat, menyebabkan konsumsi masyarakat juga meningkat dibandingkan sebelum adanya pandemi. Penelitian ini bertujuan untuk mengetahui tingkat konsumsi masyarakat melalui e-commerce sebelum dan sesudah pandemi Covid-19. Objek penelitian ini adalah mahasiswa UPN Veteran Jakarta dan beberapa masyarakat yang menggunakan e-commerce. Jenis penelitian yang digunakan merupakan penelitian kuantitatif dengan instrumen berupa kuesioner online, serta teknik analisis data kuantitatif deskriptif. Hasil penelitian menunjukkan bahwa tingkat konsumsi masyarakat melalui e-commerce meningkat setelah adanya pandemi covid-19. Masyarakat percaya terhadap sistem tersebut, mereka juga mengklaim bahwa biaya yang dikeluarkan melalui e-commerce relatif murah dibandingkan dengan berbelanja secara langsung.
\end{abstract}

Kata kunci: Belanja Online; Covid-19; E-commerce; Kuesioner Online

\section{Pendahuluan}

Dunia saat ini sedang menghadapi sebuah wabah virus yang berasal dari kota Wuhan, China. Virus ini disebut Covid-19 (Corona Virus Disease 2019). Secara resmi virus ini dianggap sudah menyebar sejak 31 Desember 2019, ketika otoritas kesehatan di kota Wuhan di China mengeluarkan peringatan tentang serangkaian kasus yang terkait dengan virus yang 
menyerang pernapasan secara misterius (BBC News Indonesia, 2020). Virus ini bisa menyebabkan gangguan ringan sistem pernapasan, infeksi paru-paru berat, hingga kematian. Dampak dari mewabahnya pandemi ini sangat terasa di berbagai negara. Berbagai bidang kehidupan merasakan dampak dari adanya pandemi ini.

Salah satu bidang yang terdampak adalah bidang ekonomi. Perekonomian di berbagai negara menjadi menurun dari adanya pandemi ini. Namun, terdapat suatu sektor yang dapat meningkatkan perekonomian negara, yaitu sektor e-commerce sebagai salah satu solusi untuk mengatasi defisit pajak akibat perlambatan ekonomi (Kusumastuti, 2020). Menurut Sudaryono et al. (2020), perusahaan-perusahaan e-commerce di Indonesia membukukan kenaikan volume penjualan dengan semakin banyaknya masyarakat yang menerapkan physical distancing di tengah wabah pandemi covid-19 saat ini.

Electronic commerce atau biasa disebut e-commerce merupakan proses transaksi jualbeli berbasis online (Harahap \& Amanah, 2018),(Khasanah et al., 2019). Pada pelaksanaannya e-commerce mencakup semua aktivitas pedagangan fisik, seperti pemasaran, pemesanan, proses pembayaran, jasa pengiriman, dan proses bargaining produk (Hermawan, 2017). Menurut Artheswara \& Sulistiawati (2020), wadah ini sangat berfungsi bagi masyarakat yang tidak bisa langsung ke tempat untuk berbelanja. Terlebih lagi dengan diterapkannya physical distancing yang dianjurkan pemerintah, hal ini sangatlah bermanfaat bagi masyarakat dalam memenuhi keperluannya sehari-hari.

Oleh karena itu, dengan adanya pandemi ini bisa membuat tingkat konsumsi masyarakat terhadap e-commerce menjadi meningkat. Hal ini juga dapat menimbulkan perilaku konsumtif bagi masyarakat. Perilaku konsumtif sendiri berarti perilaku atau sikap saat membeli suatu barang hanya untuk memenuhi kepuasan, bukan untuk kebutuhan sehingga menyebabkan keborosan (Marindi \& Nurwidawati, 2015).

Selain itu, dari adanya pandemi ini, tingkat konsumsi masyarakat bisa juga menurun karena kesulitan keuangan yang sedang dihadapi. Tergantung kebijakan setiap individu dalam pemanfaatan kemudahan yang dimiliki e-commerce.

Menurut Adhani et al., (2020), perilaku belanja online dapat dinyatakan sebagai aktifitas dari keputusan masyarakat sendiri saat akan membeli suatu produk. Keinginan personal dan psikologis merupakan faktor yang data memengaruhi keputusan tersebut (Singh et al., 2014). Keinginan personal diinterpretasikan melalui demografi survey seperti usia, pekerjaan dan aktifitas personal (frekuensi belanja, frekuensi menggunakan smartphone, dan lainnya). Sementara itu, faktor psikologisnya itu dari prefensi konumen sebelum mendapatkan produk yang diinginkan, atau bisa disebut dengan prefensi spesifikasi produk.

Penggunaan e-commerce telah menjadi suatu tren yang mendunia, khususnya di kalangan masyarakat Indonesia. Telah dibuktikan oleh Himmgiry Chaudary di India dari penelitiannya yang berjudul "Analyzing the Paradigm Shift of Consumer Behavior Towards Ecommerce During Pandemic Lockdown". Hasil survey ini menunjukkan bahwa tingkat kepuasan masyarakat atau konsumen yang tinggi menyebabkan pemakaian e-commerce meningkat, 
bahkan mereka lebih percaya pada industri e-commerce daripada membeli barang secara langsung. Terlebih lagi sejak penerapan lockdown akibat pandemi covid-19, yang diterapkan oleh pemerintah, menyebabkan permintaan barang secara online melonjak tinggi (Chaudhary, 2020).

Perkembangan penggunaan e-commerce yang pesat telah menjadi gaya hidup tersendiri terutama masyarakat perkotaan (Mufarida, 2011). Tidak hanya masyarakat biasa, bahkan kalangan remaja pun menunjukkan kegemarannya berbelanja melalui situs online. Perilaku tersebut dapat dilihat dari platform atau aplikasi populer seperti Instagram dan Shopee. Mereka menawarkan berbagai produk untuk memenuhi kebutuhan kita, mulai dari pakaian hingga alat elektronik (Hamsinar, 2019), (Khasanah et al., 2020). Selain penggunaannya yang terbilang mudah dan praktis, adanya PSBB (Pembatasan Sosial Berskala Besar), aturan pemerintah yang mengharuskan masyarakat untuk mengurangi kegiatan di luar rumah hingga meningkatnya angka kasus positif covid-19 menyebabkan masyarakat lebih berminat pada layanan e-commerce.

Oleh karena itu, dalam penelitian ini, peneliti memiliki tujuan untuk mengetahui perbandingan tingkat konsumsi masyarakat dalam belanja melalui e-commerce sebelum dan sesuadah pandemi melanda dunia. Melalui penelitian ini, diharapkan peneliti dapat memberikan gambaran mengenai seberapa besar tingkat perbandingan tingkat konsumsi masyarakat melalui e-commerce sebelum dan sesudah pandemi melanda dunia.

Penelitian yang dilakukan oleh (Adhani et al., 2020) menunjukkan bahwa selama masa pandemi Covid-19, perilaku konsumen mengalami perubahan dalam intensitas belanja online, mereka cenderung tertarik berbelanja melalui online terutama produk kesehatan. Selain itu, penelitian yang dilakukan oleh (Sumarni et al., 2020) menunjukkan bahwa selama masa pandemi Covid-19, Ibu rumah tangga sangat menyukai belanja online berbasis E-commerce.

Terdapat juga penelitian yang berjudul "Pengaruh Penggunaan E-commerce dalam Proses Penjualan terhadap Minat Berwirausaha Siswa SMK Negeri Ngraho", mereka menggunakan penelitian kuantitatif untuk menguji hipotesis yang telah ditentukan, serta menetapkan populasi dan beberapa responden atau sampel untuk mendukung proses penelitian (Sari \& Wibawa, 2017). Hasil penelitian tersebut menunjukkan terdapat pengaruh penggunaan sesudah menggunakan E-commerce yang dapat mempermudah kesulitan proses bertransaksi jual beli produk kriya siswa SMK Negeri Ngraho.

Berdasarkan beberapa pertimbangan tersebut, kami menyimpulkan fokus penelitian dan hipotesis mengenai perbandingan penggunaan e-commerce di Indonesia sebelum dan sesudah pandemi covid-19. Terdapat hipotesis sebagai berikut yaitu tingkat penggunaan dan konsumsi masyarakat terhadap e-commerce sebelum pandemi lebih tinggi daripada setelah pandemi covid-19 ataupun sebaliknya. Menurut kami karena didukung oleh situasi dimana pandemi covid-19 telah melanda Indonesia, penerapan lockdown atau PSBB, beberapa protokol kesehatan serta anjuran untuk tetap di rumah, maka hasil penelitian akan 
menunjukkan tingkat konsumsi masyarakat terhadap e-commerce lebih tinggi dibandingkan sebelum adanya pandemi Covid-19.

\section{Metode Penelitian}

Penelitian ini merupakan penelitian deskriptif dengan pendekatan metode kuantitatif. Menurut Sugiyono (2010), penelitian dengan metode kuantitatif dapat memberikan data yang akurat, karena dinilai menggunakan angka atau statistik, sehingga mampu memperjelas masalah yang diteliti. Peneliti menggunakan metode ini dikarenakan peneliti mendasarkan penelitiannya yang bejudul Studi Komparasi Tingkat Konsumtif Masyarakat melalui Ecommerce Sebelum dan Sesudah Pandemi Covid-19 pada penyelidikan jumlah atau frekuensi suatu kejadian (Wulandari, 2019).

Adapun teknik pengumpulan data yang digunakan oleh peneliti yaitu dengan membagikan link kuesioner g-form kepada responden. G-form atau Google Form merupakan salah satu komponen dari fitur Google Docs. Menurut Batubara (2016), G-form sangat bermanfaat dan memudahkan, karena dapat dibagikan kepada seluruh orang secara terbuka. Pembagian link kuesioner kepada responden ini dibagikan selama 5 hari, dimulai dari tanggal 10 Desember 2020 hingga 14 Desember 2020. Responden yang dimaksud dalam penelitian ini adalah mahasiswa UPN "Veteran" Jakarta dan masyarakat Indonesia yang menggunakan ecommerce.

Untuk menganalis data yang sudah terkumpul, peneliti menggunakan teknik analisis data kuantitatif deskriptif. Di mana peneliti akan menyajikan diagram histogram dan mencari tendensi sentralnya yaitu mean, median dan modus. Data mean digunakan untuk mengetahui nilai rata-rata dari keseluruhan jawaban yang diberikan responden. Data median digunakan untuk mengetahui nilai tengah dari keseluruhan jawaban yang diberikan oleh responden. Sedangkan modus digunakan untuk mengetahui jawaban mana yang paling banyak diberikan responden dari keseluruhan jawaban yang diberikan. Selain itu peneliti juga menggunakan bantuan software statistik yaitu Statistika dan Data (STATA) versi 12.

Menurut penelitian yang dilakukan oleh (Mukhlis et al., 2020) software STATA merupakan alat analisis berupa regresi dan kolerasi untuk mengukur seberapa kuat hubungan antar varibel dependen dan independen. Dimana variabel dependen merupakan variabel yang akan diprediksi, sedangkan variabel independen adalah variabel yang menyediakan informasi dalam proses estimasi. Untuk menguji validitas antara dua variabel atau hipotesis yang telah ditetapkan, digunakan analisis uji sampel bebas atau uji-t terpisah (Independent Sampel t-Test) serta ketentuan pengujian dilakukan pada tingkat kepercayan $95 \%$ dan taraf signifikan $5 \%$ $(0,05)$ (Marliani et al., 2017). Kriteria penerimaan dan penolakan hipotesis, jika thitung $>t_{\text {tabel, }}$ atau signifikan probabilitas $\leq 0.05$, maka hipotesis nol $\left(\mathrm{H}_{0}\right)$ ditolak dan hipotesis alternatif $\left(\mathrm{H}_{1}\right)$ diterima, sedangkan jika jika thitung $\leq t_{\text {tabel, }}$, atau signifikan probabilitas $>0.05$, maka hipotesis nol $\left(\mathrm{H}_{0}\right)$ diterima dan hipotesis alternatif $\left(\mathrm{H}_{1}\right)$ ditolak (Irsyadi, 2012). 
$\bar{x}=\sum_{i=1}^{n} \frac{x_{i}}{n}$

Keterangan: $\overline{\bar{x}}$ : mean; $n$ : jumlah data/sampel; $x_{i:}$ total frekuensi/banyaknya pilihan responden

$n=2 k+1$

$k=\frac{n-1}{2}$

Median $=x_{k+1}$

Keterangan: n: banyaknya data/jumlah sampel; k: untuk menentukan letak nilai median

Oleh karena itu, penggunaan metode kuantitatif dalam penelitian ini diharapkan dapat memberikan hasil data yang pasti dan relevan terkait perbandingan tingkat konsumtif masyarakat dalam penggunaan e-commerce sebelum dan sesudah pandemi covid-19. Dan penggunaan teknik pengumpulan data yang digunakan peneliti ini diharapkan dapat memberikan kemudahan di tengah pandemi ini, baik kemudahan bagi peneliti dalam hal pengumpulan data, maupun bagi responden dalam pemberian jawaban.

\section{Hasil dan Pembahasan}

\subsection{Deskripsi Data}

Penelitian ini merupakan penelitian kuantitatif yang dilaksanakan mulai tanggal $10-14$ Desember 2020. Penelitian ini diperoleh dengan membagikan kuisioner online terhadap mahasiswa UPN "Veteran" Jakarta dan masyarakat Indonesia yang menggunakan ecommerce. Metode analisis data menggunakan data kuantitatif deskriptif. Adapun data hasil kuisioner yang kami lakukan sebagai berikut:

Tabel 1. Distribusi Frekuensi Penyebaran Kuesioner

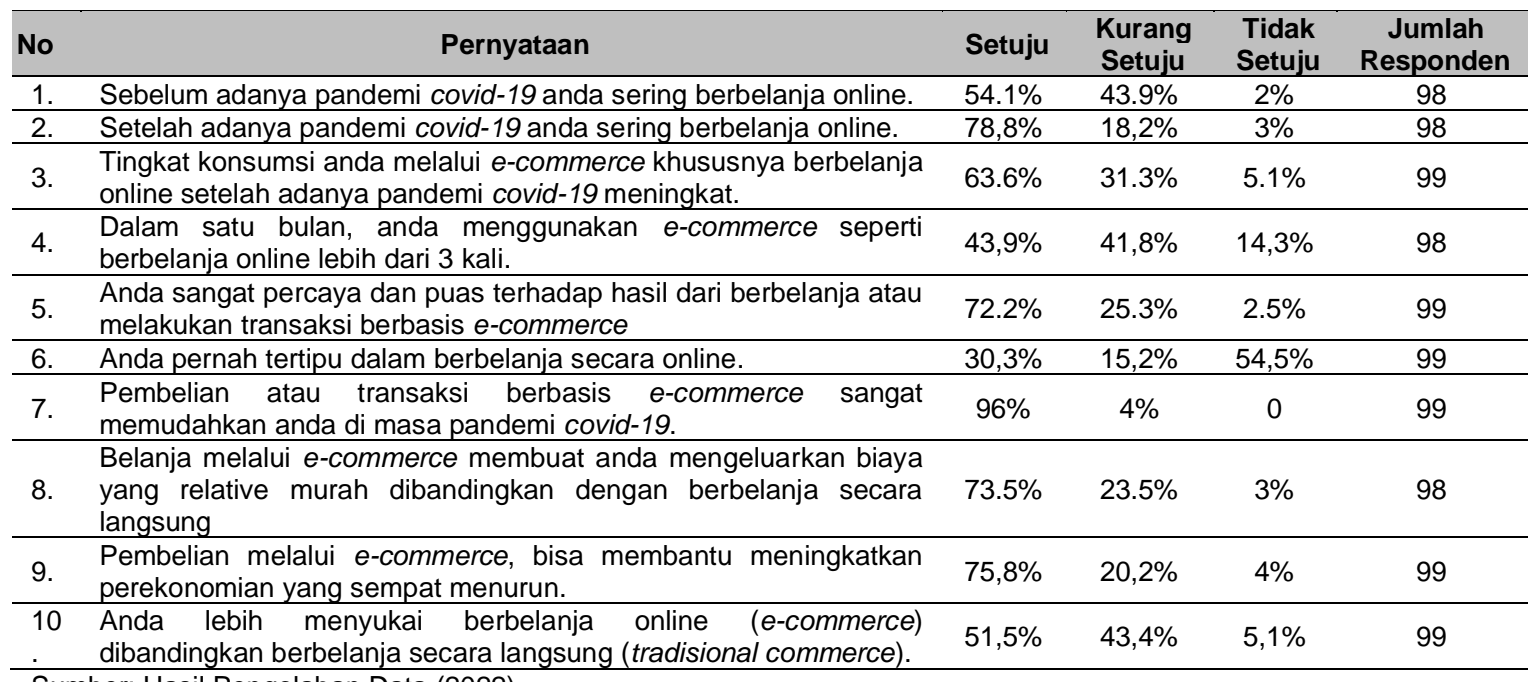

Sumber: Hasil Pengolahan Data (2022) 
Dalam penyebaran kuisioner, dilakukan dengan menyebarkan 1 kuisioner berisi 10 indikator. Kuisioner diberikan kepada responden dan diharapkan agar responden dapat mengisi pernyataan-pernyataan yang diajukan pada kuesioner sesuai dengan keadaan sebenarnya.

\subsection{Hasil Penelitian}

Berdasarkan hasil penelitian yang telah dilakukan, hasil penelitian disajikan dalam bentuk penyajian data yang sesuai dengan hasil pengukuran yang dilakukan sebelumnya. Penelitian ini terlaksana karena dari sampel yang dijadikan responden untuk diambil data-data tentang tingkat konsumsi masyarakat melalui e-commerce sebelum dan sesudah pandemi covid-19.

Penyajian data terkait pernyataan tentang tingkat keseringan belanja online sebelum pandemi covid-19 ditunjukkan pada gambar 1.

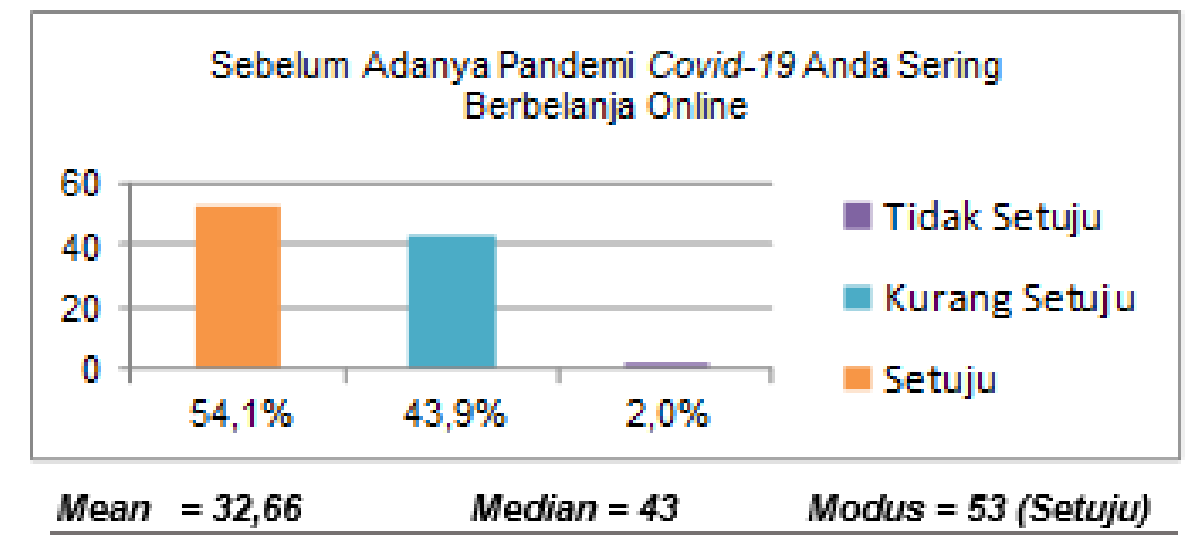

Sumber: Hasil Pengolahan Data (2022)

Gambar 1. Distribusi Pernyataan 1

Deskripsi pernyataan tentang tingkat belanja online sebelum pandemi covid-19 dengan jumlah resonden sebanyak 98 orang, diketahui harga mean $=32,66$, median $=43$ (Kurang setuju) dan modus = 53 (Setuju). Di mana responden yang setuju dengan pernyataan tersebut sebanyak 53 orang $(54.1 \%)$, kurang setuju sebanyak 43 orang $(43.9 \%)$ dan tidak setuju sebanyak 2 orang (2\%).

Berdasarkan hasil analisis di software STATA, kami menggunakan tingkat kepercayaan $95 \%$ sehingga diperoleh $t_{\text {tabel }}=1,66$, ditetapkan hipotesis penelitian sebagai berikut; $H_{0}=$ Sebelum adanya pandemi covid-19 anda jarang berbelanja online; $\mathrm{H}_{1}=$ Sebelum adanya pandemi covid-19 anda sering berbelanja online.

Signifikansi untuk variabel ini menunjukkan probabilitas $p=0,0000$ lebih kecil dari signifikansi alpha $(\alpha)$ sebesar $5 \%(0,05)$ dan thitung $=8,7652$ lebih besar daripada tabel. Sehingga diperoleh hipotesis nol $\left(\mathrm{H}_{0}\right)$ ditolak dan hipotesis alternatif $\left(\mathrm{H}_{1}\right)$ diterima, maka sebelum adanya pandemi covid-19 responden sering berbelanja online.

Penyajian data terkait pernyataan tentang tingkat keseringan belanja online setelah pandemi Covid-19. Deskripsi pernyataan tentang tingkat belanja online setelah pandemi covid- 
19 dengan jumlah resonden sebanyak 99 orang, diketahui harga mean $=33$, median $=18$ (Kurang setuju) dan modus $=78$ (Setuju). Di mana responden yang setuju dengan pernyataan tersebut sebanyak 78 orang $(78,4 \%)$, kurang setuju sebanyak 18 orang $(18,2 \%)$ dan tidak setuju sebanyak 3 orang (3\%).

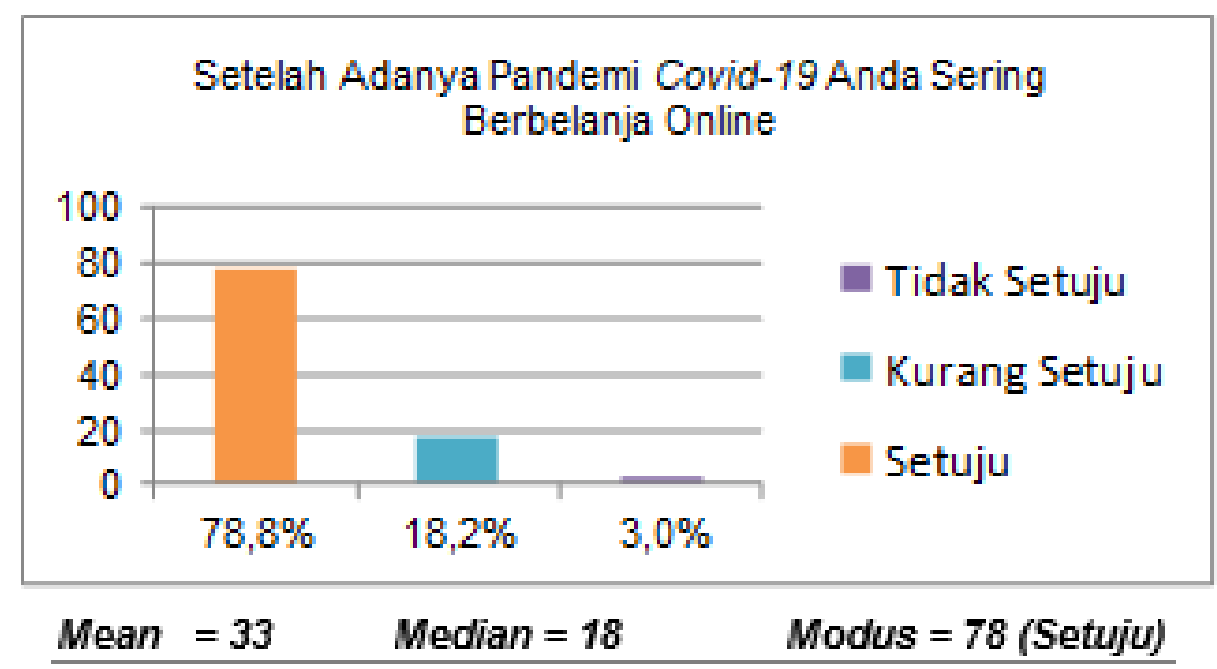

Sumber: Hasil Pengolahan Data (2022)

Gambar 2. Distribusi Pernyataan 2

Berdasarkan hasil analisis di software STATA, kami menggunakan tingkat kepercayaan $95 \%$ sehingga diperoleh $t_{\text {tabel }}=1,66$, ditetapkan hipotesis penelitian sebagai berikut. $\mathrm{H}_{0}=$ Setelah adanya pandemi covid-19 anda jarang berbelanja online; $\mathrm{H}_{1}=$ Setelah adanya pandemi covid-19 anda sering berbelanja online.

Signifikansi untuk variabel ini menunjukkan probabilitas $p=0,0000$ lebih kecil dari signifikansi alpha $(\alpha)$ sebesar $5 \%(0,05)$ dan thitung $=4.7693$ lebih besar daripada tabel. Sehingga diperoleh hipotesis nol $\left(\mathrm{H}_{0}\right)$ ditolak dan hipotesis alternatif $\left(\mathrm{H}_{1}\right)$ diterima, maka setelah adanya pandemi covid-19 responden sering berbelanja online.

Penyajian data terkait pernyataan tentang peningkatan tingkat konsumsi melalui $e$ commerce setelah pandemic ditunjuukan gambar 3 .

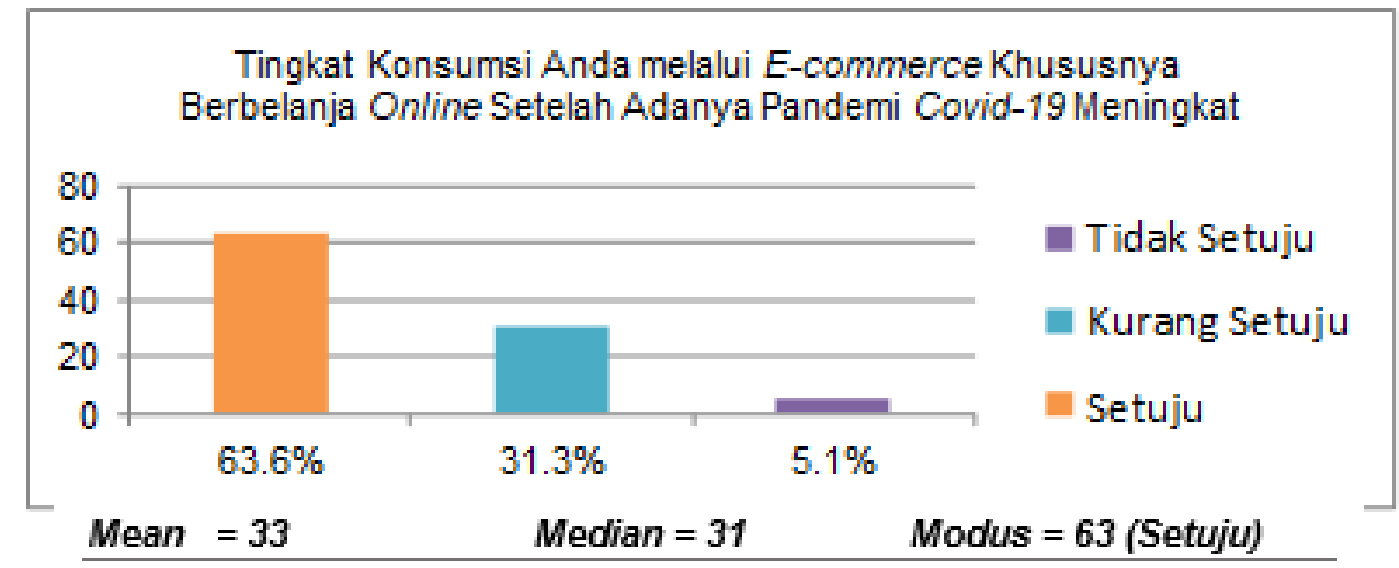

Sumber: Hasil Pengolahan Data (2022)

Gambar 3. Distribusi Pernyataan 3 
Deskripsi pernyataan tentang tingkat konsumsi terhadap E-commerce setelah pandemi covid-19 dengan jumlah resonden sebanyak 99 orang, diketahui harga mean $=33$, median $=31$ (Kurang setuju) dan modus $=63$ (Setuju). Di mana responden yang setuju dengan pernyataan tersebut sebanyak 63 orang $(63,6 \%)$, kurang setuju sebanyak 31 orang $(31,3 \%)$ dan tidak setuju sebanyak 5 orang $(5,1 \%)$.

Berdasarkan hasil analisis di software STATA, kami menggunakan tingkat kepercayaan $95 \%$ sehingga diperoleh $t_{\text {tabel }}=1,66$, ditetapkan hipotesis penelitian sebagai berikut: $\mathrm{H}_{0}=$ Setelah adanya pandemi covid-19, tingkat konsumsi responden melalui e-commerce menurun; $\mathrm{H}_{1}=$ Setelah adanya pandemi covid-19, tingkat konsumsi responden melalui e-commerce meningkat.

Signifikansi untuk variabel ini menunjukkan probabilitas $p=0,0000$ lebih kecil dari signifikansi alpha $(\alpha)$ sebesar $5 \%(0,05)$ dan thitung $=6.9155$ lebih besar daripada tabel. Sehingga diperoleh hipotesis nol $\left(\mathrm{H}_{0}\right)$ ditolak dan hipotesis alternatif $\left(\mathrm{H}_{1}\right)$ diterima, maka setelah adanya pandemi covid-19 tingkat konsumsi responden melalui e-commerce meningkat khususnya berbelanja online.

Penyajian data terkait pernyataan tentang tingkat penggunaan e-commerce dalam satu bulan. Deskripsi pernyataan tentang tingkat pengguaan E-commerce dalam satu bulan lebih dari 3 kali dengan jumlah resonden sebanyak 98 orang, diketahui harga mean $=32,66$, median $=41$ (Kurang setuju) dan modus $=43$ (Setuju). Di mana responden yang setuju dengan pernyataan tersebut sebanyak 43 orang $(43,9 \%)$, kurang setuju sebanyak 41 orang $(41,8 \%)$ dan tidak setuju sebanyak 14 orang $(14,3 \%)$.

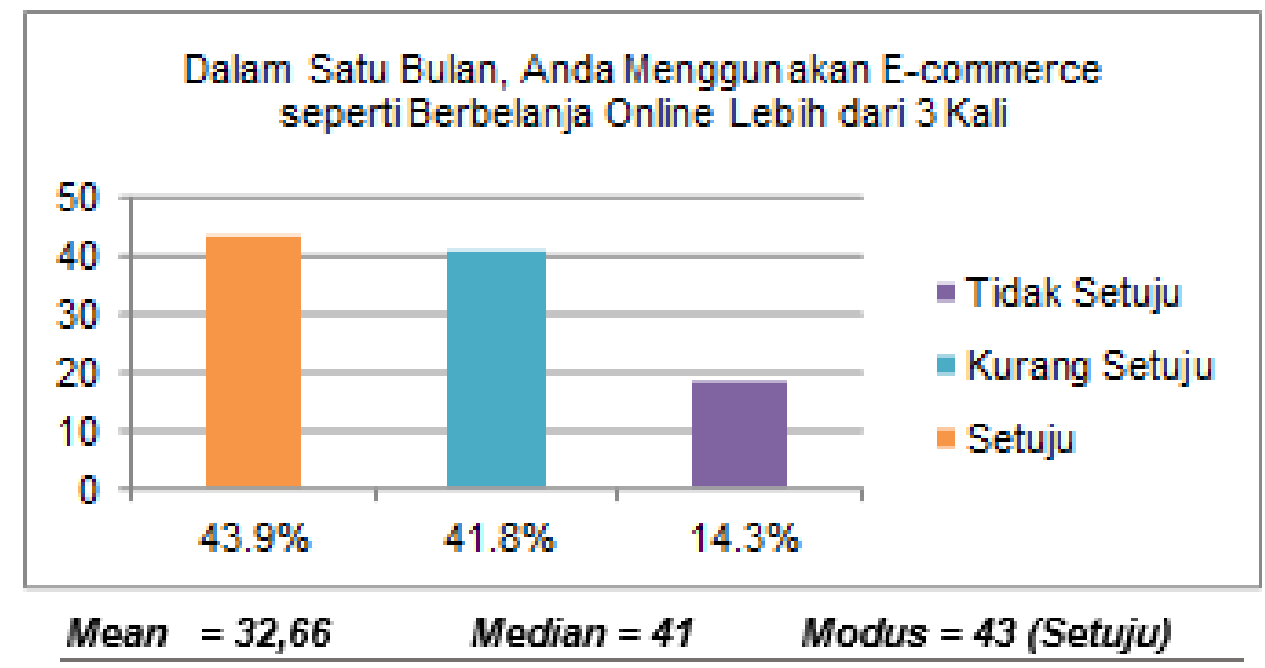

Sumber: Hasil Pengolahan Data (2022)

Gambar 4. Distribusi Pernyataan 4

Berdasarkan hasil analisis di software STATA, kami menggunakan tingkat kepercayaan $95 \%$ sehingga diperoleh $t_{\text {tabel }}=1,66$, ditetapkan hipotesis penelitian sebagai berikut $\mathrm{H}_{0}=$ Responden menggunakan e-commerce dalam satu bulan kurang dari tiga kali; $\mathrm{H}_{1}=$ Responden menggunakan e-commerce dalam satu bulan lebih dari tiga kali. 
Signifikansi untuk variabel ini menunjukkan probabilitas $p=0,0000$ lebih kecil dari signifikansi alpha $(\alpha)$ sebesar $5 \%(0,05)$ dan thitung $=9.8654$ lebih besar daripada tabel. Sehingga diperoleh hipotesis nol $\left(\mathrm{H}_{0}\right)$ ditolak dan hipotesis alternatif $\left(\mathrm{H}_{1}\right)$ diterima, maka dalam satu bulan responden menggunakan e-commerce lebih dari tiga kali khususnya berbelanja online.

Penyajian data terkait pernyataan tentang kepercayaan dan kepuasan terhadap hasil dari penggunaan e-commerce. Deskripsi pernyataan tentang tingkat kepercayaan dan kepuasan terhadap hasil berbelanja atau transaksi berbasis E-commerce dengan jumlah resonden sebanyak 99 orang, diketahui harga mean $=33$, median $=25$ (Kurang setuju) dan modus $=72$ (Setuju). Di mana responden yang setuju dengan pernyataan tersebut sebanyak 72 orang $(72,7 \%)$, kurang setuju sebanyak 25 orang $(25,3 \%)$ dan tidak setuju sebanyak 2 orang $(2 \%)$.

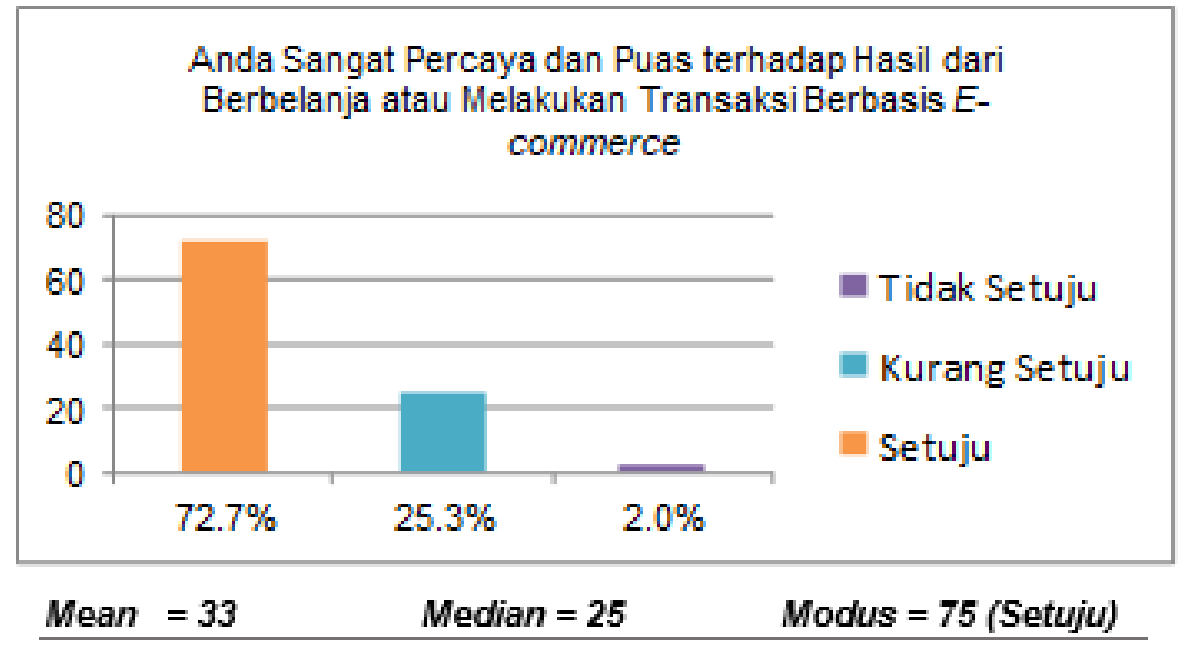

Sumber: Hasil Pengolahan Data (2022)

\section{Gambar 5. Distribusi Pernyataan 5}

Berdasarkan hasil analisis di software STATA, kami menggunakan tingkat kepercayaan $95 \%$ sehingga diperoleh $t_{\text {tabel }}=1,66$, ditetapkan hipotesis penelitian sebagai berikut: $H_{0}=$ Responden tidak puas terhadap hasil dari berbelanja atau melakukan transaksi berbasis $e$ commerce; $\mathrm{H}_{1}=$ Responden sangat puas dan percaya terhadap hasil dari berbelanja atau melakukan transaksi berbasis e-commerce. Signifikansi untuk variabel ini menunjukkan probabilitas $p=0,0000$ lebih kecil dari signifikansi alpha $(\alpha)$ sebesar $5 \%(0,05)$ dan thitung $=$ 5.7850 lebih besar daripada tabel. Sehingga diperoleh hipotesis nol $\left(\mathrm{H}_{0}\right)$ ditolak dan hipotesis alternatif $\left(\mathrm{H}_{1}\right)$ diterima, responden atau masyarakat sangat puas dan percaya terhadap hasil dari berbelanja atau melakukan transaksi berbasis e-commerce.

Penyajian data terkait pernyataan tentang penipuan dalam berbelanja online. Deskripsi pernyataan tentang tingkat kepercayaan dan kepuasan terhadap hasil berbelanja atau transaksi berbasis $E$-commerce dengan jumlah resonden sebanyak 99 orang, diketahui harga mean $=33$, median $=30$ (Setuju) dan modus $=54$ (Tidak Setuju). Di mana responden yang setuju dengan pernyataan tersebut sebanyak 30 orang $(30,3 \%)$, kurang setuju sebanyak 15 orang $(15,2 \%)$ dan tidak setuju sebanyak 54 orang $(54,5 \%)$. 


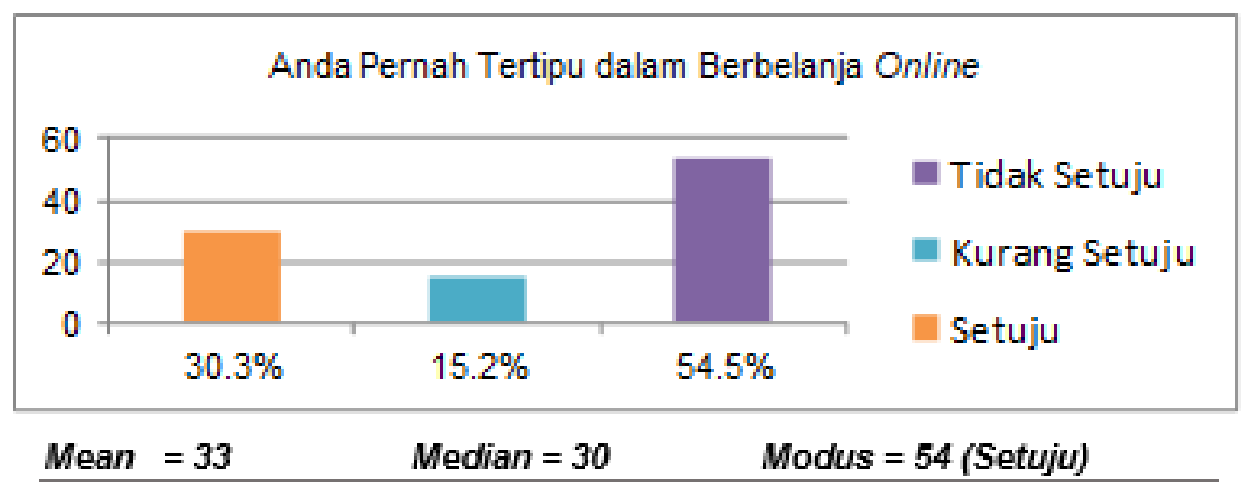

Sumber: Hasil Pengolahan Data (2022)

Gambar 6. Distribusi Pernyataan 6

Berdasarkan hasil analisis di software STATA, kami menggunakan tingkat kepercayaan $95 \%$ sehingga diperoleh $t_{\text {tabel }}=1,66$, ditetapkan hipotesis penelitian sebagai berikut: $\mathrm{H}_{0}=$ Responden tidak pernah tertipu dalam berbelanja online; $\mathrm{H}_{1}=$ Responden sering tertipu dalam berbelanja online.

Signifikansi untuk variabel ini menunjukkan probabilitas $p=0,0000$ lebih kecil dari signifikansi alpha $(\alpha)$ sebesar $5 \%(0,05)$ dan thitung $=-8,4703$ lebih kecil daripada tabel. Sehingga diperoleh hipotesis nol $\left(\mathrm{H}_{0}\right)$ diterima dan hipotesis alternatif $\left(\mathrm{H}_{1}\right)$ ditolak, maka responden atau masyarakat jarang sekali tertipu saat berbelanja di e-commerce.

Penyajian data terkait kemudahan yang diberikan dari e-commerce ketika pandemi Covid19. Deskripsi pernyataan tentang pembelian dan transaksi berbasis E-commerce sangat memudahkan di masa pandemi Covid-19 dengan jumlah resonden sebanyak 99 orang, diketahui harga mean $=33$, median $=4$ (Tidak setuju) dan modus $=95$ (Setuju). Di mana responden yang setuju dengan pernyataan tersebut sebanyak 95 orang $(96 \%)$, tidak ada yang menjawab kurang setuju dan tidak setuju sebanyak 4 orang (4\%).

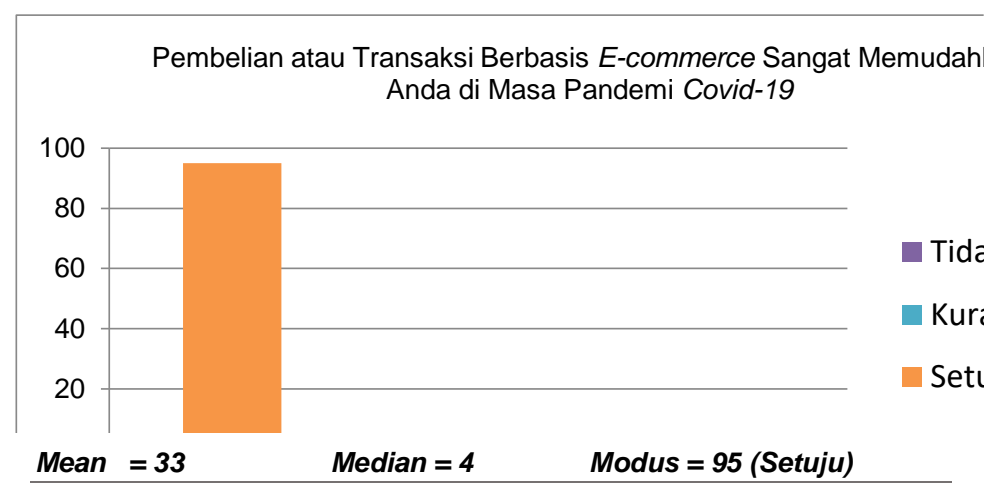

Sumber: Hasil Pengolahan Data (2022)

Gambar 7. Distribusi Pernyataan 7

Berdasarkan hasil analisis di software STATA, kami menggunakan tingkat kepercayaan $95 \%$ sehingga diperoleh $t_{\text {tabel }}=1,66$, ditetapkan hipotesis penelitian sebagai berikut: $\mathrm{H}_{0}=$ Pembelian atau transaksi berbasis e-commerce lebih menyulitkan responden dibandingkan 
berbelanja langsung disaat pandemic Covid-19; $\mathrm{H}_{1}=$ Pembelian atau transaksi berbasis $e-$ commerce sangat memudahkan responden disaat pandemic Covid-19.

Signifikansi untuk variabel ini menunjukkan probabilitas $p=0,0000$ lebih kecil dari signifikansi alpha $(\alpha)$ sebesar $5 \%(0,05)$ dan thitung $=1,7502$ lebih besar daripada tabel. Sehingga diperoleh hipotesis nol $\left(\mathrm{H}_{0}\right)$ ditolak dan hipotesis alternatif $\left(\mathrm{H}_{1}\right)$ diterima, responden atau masyarakat merasa dimudahkan dalam proses transaksi di e-commerce selama masa pandemi.

Penyajian data terkait pernyataan tentang pengeluaran biaya ketika belanja melalui $e$ commerce yang relatif murah. Deskripsi pernyataan tentang belanja melalui E-commerce mengeluarkan biaya yang relatif murah dibandingkan secara langsung atau tradisional dengan jumlah resonden sebanyak 98 orang, diketahui harga mean $=32,66$, median $=23$ (Kurang setuju) dan modus $=72$ (Setuju). Di mana responden yang setuju dengan pernyataan tersebut sebanyak 72 orang $(73,5 \%)$, kurang setuju sebanyak 23 orang $(23,5 \%)$ dan tidak setuju sebanyak 3 orang (3\%).

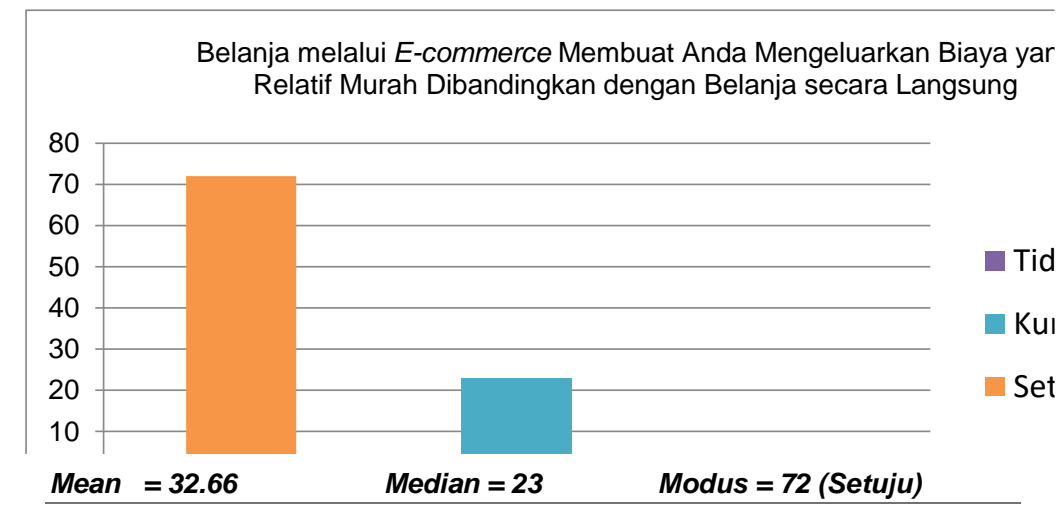

Sumber: Hasil Pengolahan Data (2022)

Gambar 8. Distribusi Pernyataan 8

Berdasarkan hasil analisis di software STATA, kami menggunakan tingkat kepercayaan $95 \%$ sehingga diperoleh tabel $=1,66$, ditetapkan hipotesis penelitian sebagai berikut: $\mathrm{H}_{0}=$ Belanja melalui e-commerce membuat responden mengeluarkan biaya yang mahal dibandingkan berbelanja secara langsung; $\mathrm{H}_{1}=$ Belanja melalui e-commerce membuat responden mengeluarkan biaya yang relatif murah dibandingkan berbelanja secara langsung. Signifikansi untuk variabel ini menunjukkan probabilitas $p=0,0000$ lebih kecil dari signifikansi alpha $(\alpha)$ sebesar $5 \%(0,05)$ dan thitung $=5,6133$ lebih besar daripada tabel. Sehingga diperoleh hipotesis nol $\left(\mathrm{H}_{0}\right)$ ditolak dan hipotesis alternatif $\left(\mathrm{H}_{1}\right)$ diterima, responden atau masyarakat mengeluarkan biaya yang relatif murah saat berbelanja di e-commerce.

Penyajian data terkait pernyataan tentang pembelian melalui e-commerce membantu peningkatan perekonomian negara. Deskripsi pernyataan tentang pembelian melalui $E$ commerce dapat membantu meningkatkan perekonomian yang sempat menurun dengan jumlah resonden sebanyak 99 orang, diketahui harga mean $=33$, median $=20$ (Kurang setuju) dan modus $=75$ (Setuju). Di mana responden yang setuju dengan pernyataan tersebut 
sebanyak 75 orang $(75,8 \%)$, kurang setuju sebanyak 20 orang $(20,2 \%)$ dan tidak setuju sebanyak 4 orang $(4 \%)$.

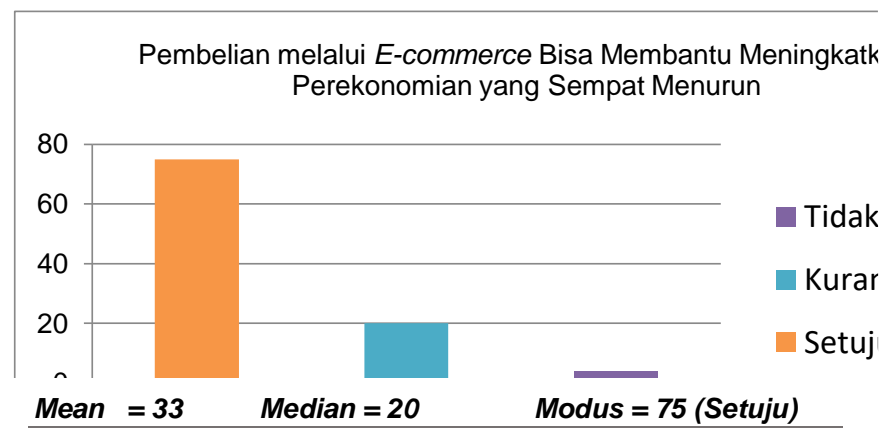

Sumber: Hasil Pengolahan Data (2022)

Gambar 9. Distribusi Pernyataan 9

Berdasarkan hasil analisis di software STATA, kami menggunakan tingkat kepercayaan $95 \%$ sehingga diperoleh tabel $=1,66$, ditetapkan hipotesis penelitian sebagai berikut: $\mathrm{H}_{0}=E$ commerce tidak dapat membantu meningkatkan perekonomian yang sedang menurun akibat pandemi Covid-19; $\mathrm{H}_{1}=$ E-commerce dapat membantu meningkatkan perekonomian yang sedang menurun akibat pandemi Covid-19.

Signifikansi untuk variabel ini menunjukkan probabilitas $p=0,0000$ lebih kecil dari signifikansi alpha $(\alpha)$ sebesar $5 \%(0,05)$ dan thitung $=5,1629$ lebih besar daripada tabel. Sehingga diperoleh hipotesis nol $\left(\mathrm{H}_{0}\right)$ ditolak dan hipotesis alternatif $\left(\mathrm{H}_{1}\right)$ diterima, maka e-commerce dapat membantu meningkatkan perekonomian yang sedang menurun akibat pandemi.

Penyajian data terkait pernyataan tentang metode yang lebih disukai dalam berbelanja. Deskripsi pernyataan tentang tingkat kesukaan berbelanja online terhadap E-commerce dibandingkan secara langsung (Traditional Commerce) dengan jumlah resonden sebanyak 99 orang, diketahui harga mean $=33$, median $=43$ (Kurang setuju) dan modus $=51$ (Setuju). Di mana responden yang setuju dengan pernyataan tersebut sebanyak 51 orang $(51,5 \%)$, kurang setuju sebanyak 43 orang $(43,4 \%)$ dan tidak setuju sebanyak 5 orang $(5,1 \%)$.

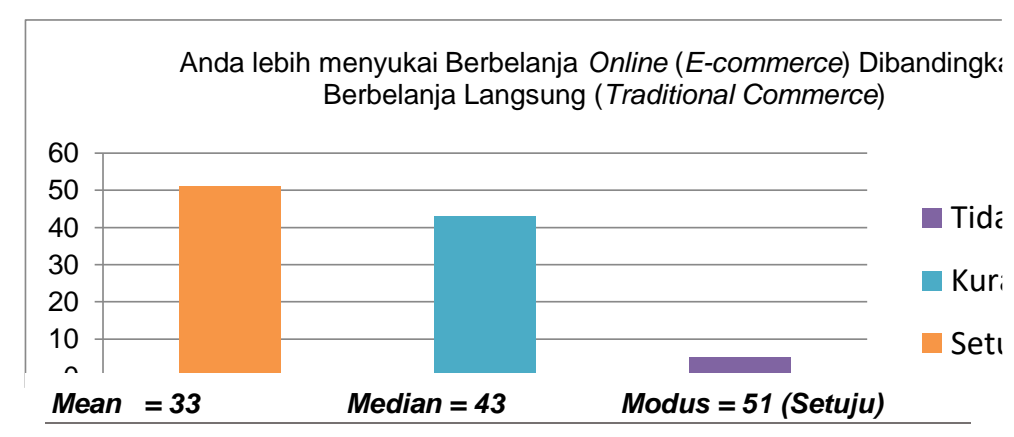

Sumber: Hasil Pengolahan Data (2022)

Gambar 10. Distribusi Pernyataan 10

Berdasarkan hasil analisis di software STATA, kami menggunakan tingkat kepercayaan $95 \%$ sehingga diperoleh $t_{\text {tabel }}=1,66$, ditetapkan hipotesis penelitian sebagai berikut: $H_{0}=$ Responden lebih menyukai traditional commerce dibandingkan e-commerce; $\mathrm{H}_{1}=$ Responden 
lebih menyukai e-commerce dibandingkan traditional commerce. Signifikansi untuk variabel ini menunjukkan probabilitas $p=0,0000$ lebih kecil dari signifikansi alpha $(\alpha)$ sebesar $5 \%(0,05)$ dan thitung $=8,9058$ lebih besar daripada tabel. Sehingga diperoleh hipotesis nol $\left(\mathrm{H}_{0}\right)$ ditolak dan hipotesis alternatif $\left(\mathrm{H}_{1}\right)$ diterima, responden atau masyarakat lebih menyukai berbelanja di $e$ commerce dibandingkan traditional commerce.

\section{Kesimpulan}

Berdasarkan hasil penelitian dan pembahasan yang telah dilakukan oleh peneliti mengenai Studi Komparasi Tingkat Konsumsi Masyarakat melalui E-commerce Sebelum dan Sesudah Masa Pandemi Covid-19, dapat disimpulkan bahwa tingkat konsumsi masyarakat melalui e-commerce meningkat setelah adanya pandemi covid-19. Hal ini dapat dilihat dari hasil persentase kuesioner pernyataan satu hingga tiga yang sebagian dari mereka setuju dengan pernyataan-pernyataan yang diberikan. Sebagian besar dari responden yang mengisi kuesioner juga berpendapat bahwa mereka lebih menyukai berbelanja online (e-commerce) dibandingkan berbelanja secara langsung (tradisional commerce). Masyarakat merasa percaya dan puas terhadap hasil yang diberikan dari penggunaan e-commerce. Terlebih lagi dengan adanya pandemi covid-19 ini, menurut mereka e-commerce sangat memudahkan mereka dalam berbelanja untuk memenuhi kebutuhan sehari-hari. Bahkan mereka menyetujui bahwa berbelanja melalui e-commerce membuat mereka mengeluarkan biaya yang relatif murah dibandingkan dengan mereka berbelanja secara langsung ke toko. Selain itu, sebagian besar responden juga setuju bahwa bertransaksi melalui e-commerce, dapat membantu meningkatkan perkeonomian negara yang sempat menurun dari adanya pandemi ini.

\section{Daftar Pustaka}

Adhani, L. K., Dharmastiti, R., \& Trapsilawati, F. (2020). Pengaruh Waktu Sebelum dan Selama Pandemi Covid-19 terhadap Perilaku Konsumen Belanja Online. 50-55.

Artheswara, L. C., \& Sulistiawati, A. (2020). Tingkat Penggunaan E-Commerce pada Remaja di Kota dan Kabupaten Bogor. Jurnal Sains Komunikasi Dan Pengembangan Masyarakat [JSKPM], 4(4), 437-448. https://doi.org/10.29244/jskpm.4.4.441-452

Batubara, H. H. (2016). Penggunaan Google Form sebagai Alat Penilaian Kinerja Dosen di Prodi PGMI UNISKA Muhammad Arsyad AI Banjari. Universitas Islam Kalimantan MAB, $8(1), 1-12$.

BBC News Indonesia. (2020, December). Covid-19: Virus corona diduga sudah menyebar sebelum pertama kali dilaporkan di China pada Desember 2019.

Chaudhary, H. (2020). Analyzing the Paradigm Shift of Consumer Behavior Towards ECommerce During Pandemic Lockdown. SSRN Electronic Journal, 1-30. https://doi.org/10.2139/ssrn.3664668

Hamsinar. (2019). Analisis Perlindungan Hak Konsumen terhadap Transaksi E-commerce Menurut Hukum Islam dan Hukum Positif (Studi pada Shopee). UIN Alauddin Makassar, $8(5), 100$.

Harahap, D. A., \& Amanah, D. (2018). Perilaku Belanja Online Di Indonesia: Studi Kasus. JRMSI - Jurnal Riset Manajemen Sains Indonesia, 9(2), 193-213. https://doi.org/10.21009/jrmsi.009.2.02

Hermawan, H. (2017). Sikap Konsumen Terhadap Belanja Online. WACANA, Jurnal IImiah IImu Komunikasi, 16(1), 136. https://doi.org/10.32509/wacana.v16i1.6

Irsyadi, A. Y. (2012). Pengaruh Bimbingan Karir dan Pola Asuh Orang Tua Terhadap 
Kemandirian Siswa Dalam Memilih Karir Pada Kelas XI Jurusan Teknik Instalasi Tenaga Listrik SMK Negeri 1 Sedayu. Jurnal Penelitian, 66, 1-15.

Khasanah, F. N., Herlawati, Samsiana, S., Trias Handayanto, R., Setyowati Srie Gunarti, A., Raharja, I., Maimunah, \& Benrahman. (2020). Pemanfaatan Media Sosial dan Ecommerce Sebagai Media Pemasaran Dalam Mendukung Peluang Usaha Mandiri Pada Masa Pandemi Covid 19. Jurnal Sains Teknologi Dalam Pemberdayaan Masyarakat, 1(1), 5162. https://doi.org/10.31599/jstpm.v1i1.255

Khasanah, F. N., Rofiah, S., \& Setiyadi, D. (2019). Metode User Centered Design Dalam Merancang Tampilan Antarmuka Ecommerce Penjualan Pupuk Berbasis Website Menggunakan Aplikasi Balsamiq Mockups. JAST: Jurnal Aplikasi Sains Dan Teknologi, 3(2), 14. https://doi.org/10.33366/jast.v3i2.1443

Kusumastuti, A. D. (2020). Pengaruh Pandemi Covid-19 Terhadap Eksistensi Bisnis UMKM dalam Mempertahankan Business Continuity Management (BCM). Jurnal Administrasi Bisnis Fisipol Unmul, 8(3), 224-232.

Marindi, P., \& Nurwidawati, D. (2015). Hubungan Antara Kepuasan Konsumen Dalam Belanja Online Dengan Perilaku Konsumtif Pada Mahasiswa Psikologi Universitas Negeri Surabaya. Character: Jurnal Penelitian Psikologi., Vol 3, No 3 (2015): Character: Jurnal Psikologi Pendidikan, 1-5.

Marliani, N., Hasanuddin, \& Nurmaliah, C. (2017). Pengaruh Model Pembelajaran Science, Tehcnologi, Society, Environment (Stse) Terhadap Keterampilan Berpikir Kritis Dan Hasil Belajar Siswa Pada Materi Pencemaran Lingkungan Di Mas Jeumala Âamal. Jurnal EduBio Tropika, 5(1), 38-43.

Mufarida, H. A. (2011). E-Commerce Consumer Behavior Among Adolescent Urban. Jurnal Universitas Airlangga.

Mukhlis, I., Yusida, E., Dwiputri, I. N., \& Yunikawati, N. A. (2020). Pelatihan Metode Dasar Statistika Pada Musyawarah Guru Mata Pelajaran ( MGMP ) Bidang Ekonomi. Jurnal Pengabdian Kepada Masyarakat, 3(1), 28-34.

Sari, D. C. K., \& Wibawa, S. C. (2017). Pengaruh Penggunaan E-commerce Dalam Proses Penjualan Terhadap Minat Berwirausaha Siswa SMK Ngraho. It-Edu, 2(01), 16-23.

Singh, A., Dhayal, N., \& Shamim, A. (2014). Consumer Buying Behaviour. Marketing Briefs: A Revision and Study Guide, 5(12), 17-21. https://doi.org/10.4324/9780080511085-13

Sudaryono, Rahwanto, E., \& Komala, R. (2020). E-commerce Dorong Perekonomian Indonesia, selama Pandemi Covid-19. Jurnal Manajemen Bisnis (JUMANIS) Prodi Kewirausahaan, 2(1), 200-213. https://doi.org/https://doi.org/10.47080/10.47080/vol1no02/jumanis

Sugiyono. (2017). Metode Penelitian Kuantitatif, Kualitatif dan R\&D.

Sumarni, N., Faddila, S. P., \& Fauji, R. (2020). Perilaku Belanja Online Pada lbu Rumah Tangga Disaat Pandemi Covid-19 (Studi Kasus Ibu Rumah Tangga di Anjun Karawang). Jurnal Manajemen Dan Bisnis Kreatif, 19, 1-22. https://doi.org/10.36805 / manajemen.v6i2.1186

Wulandari, M. R. (2019). Analisis Perbandingan Tingkat Pengetahuan Peringatan Dini di Sekolah Muhammadiyah di Kabupaten Karanganyar. Tunas Geografi, 8(1), 33-43. https://doi.org/10.24114/tgeo.v8i1.12156 